\title{
Site- and tree-related factors affecting colonization of cork oaks Quercus suber L. by ambrosia beetles in Tunisia
}

\author{
Amani Bellahirech ${ }^{1,2}$ (D) Manuela Branco ${ }^{3} \cdot$ Filipe X. Catry ${ }^{4} \cdot$ Luis Bonifácio $^{5} \cdot$ Edmundo Sousa $^{5}$. \\ Mohamed Lahbib Ben Jamâa ${ }^{1}$
}

Received: 17 July 2018 / Accepted: 4 March 2019 / Published online: 26 April 2019

(C) INRA and Springer-Verlag France SAS, part of Springer Nature 2019

\begin{abstract}
- Key message Ambrosia beetles are emerging globally as important agents of tree death and decline. In this work, we observed highly variable attack intensity by ambrosia beetles in cork oak stands in Tunisia. A correlation between the proportion of infested trees and average temperature was found. Tree diameter and tree phytosanitary variables further contribute to the attack densities of ambrosia beetles. Results can be relevant for preventive measures aiming to conserve this natural forest heritage.

- Context Cork oak woodlands comprise a unique Mediterranean ecosystem supporting rich biological diversity and providing multiple services. A decline of cork oak forests has been observed in several regions of the Mediterranean Basin in the last four decades, which can be related to climate change, novel biotic agents, and changes in management practices. The ambrosia beetles have been one of the major biotic agents associated with cork oak decline, mostly in the western Mediterranean.

- Aims Assess the presence and attack densities of ambrosia beetles in cork oak Tunisian forests.

- Methods A total of 15 sites located in North Western of Tunisia, comprising 729 sample trees were evaluated. Using generalized linear models, the presence and density of ambrosia beetles' holes were related to tree and site variables. Variables related to climate, tree (dendrometric parameters, debarking intensity) and biotic agents were examined.

- Results The proportion of trees attacked per site varied from 0 to $100 \%$; in four sites, it exceeded $50 \%$. At the site level, the average temperature and tree diameter were the main variables explaining the proportion of attacked trees. Sites with warmer climates showed higher incidence of ambrosia beetles. At the tree level, the presence of attacks increased with tree diameter and concomitantly with intensity of debarking, as well as the presence of tree trunk cavities.
\end{abstract}

\section{Handling Editor: Aurélien Sallé}

Contribution of co-authors

A.B., E.S., L.B. and M.L.B.J. conceived and planned the experiments.

A.B. and M.L.B.J. collected and processed the data.

M.B. and F.C. performed the statistical analyses, derived the models and elaborated the results.

A.B. and M.B. wrote the first draft of the manuscript.

All authors contribute to the writing of the final manuscript

This article is part of the topical collection on Entomological issues during forest diebacks

Amani Bellahirech

amany21@ hotmail.fr

1 National Research Institute of Rural Engineering, Water and Forests, Rue Hédi Karray, El Menzah IV, B.P. No. 10, 2080 Ariana, Tunisia

2 National Institute of Agronomy, Tunis, 43 Avenue Charles Nicolle, 1082 Tunis, Tunisia
3 Centro de Estudos Florestais, Instituto Superior de Agronomia, Universidade de Lisboa, Tapada da Ajuda, 1349-017 Lisbon, Portugal

4 Centro de Ecologia Aplicada "Prof. Baeta Neves" (CEABN/InBIO), Instituto Superior de Agronomia, Universidade de Lisboa, Tapada da Ajuda, 1349-017 Lisbon, Portugal

5 Unidade Estratégica de Sistemas Agrários e Florestais e Sanidade Vegetal, Instituto de Investigação Agrária e Veterinária, IP, Av. da República, Quinta do Marquês, 2780-159 Oeiras, Portugal 
- Conclusion The presence and density of insect attacks were related to tree diameter, area of debarking, and phytosanitary conditions. However, $19 \%$ of the trees attacked by ambrosia beetles had no signs of other biotic agents or decline. At the site level, attack rates increased with temperature and tree diameter. A warmer climate may change insect behavior from that of a nonaggressive pest to that of an aggressive bark beetle. Adaptive forest management practices are needed to reduce infestations.

Keywords Platypus cylindrus $\cdot$ Climate $\cdot$ Tree decline $\cdot$ Forest management $\cdot$ Forest risk $\cdot$ Temperature

\section{Introduction}

Cork oak, Quercus suber L., is an evergreen oak well known for its characteristic thick outer bark (cork) from which several products are made. The species is distributed along the south and north rims of the western Mediterranean Basin. Cork oak has been exploited since ancient times for cork, acorns (still used to feed animals in agroforest systems), and charcoal (Bugalho et al. 2011; Costa et al. 2011). The largest areas of cork oak in the world are present in the Iberian Peninsula, where cork oak is often kept in a savannah-type agroforest system with low tree density $\left(60-200\right.$ trees ha $\left.{ }^{-1}\right)$. These areas are frequently combined with pastures or agricultural crops, with high local and national socio-economic importance, typically known as "dehesas" in Spain and "montado" in Portugal (Mendes and Graça 2009). Cork oak forests are also important ecosystems in Northwestern African countries (Aronson et al. 2009) and South Italy (Pereira et al. 2008). These unique ecosystems are hotspots of biodiversity, including numerous endemic species (Bugalho et al. 2011; Mazzei et al. 2018).

During the last four decades, a decline of cork oak has been observed in most Mediterranean countries, varying in intensity. Degradation of cork oak forests in Northwest Africa regions is mostly credited to overexploitation of trees (e.g., over-logging), overgrazing, intensive land use and urbanization (Campos 2004; Daly et al. 2009). In the Iberian Peninsula, the decline of oak woodlands has been reported since the 1980s and was attributed to a range of factors including not only pests and diseases (Costa et al. 2011; Montoya 1988) but also climate, wildfires, and abiotic factors related to human activity (Acácio et al. 2017; Catry et al. 2012; Pausas et al. 2009; Silva and Catry 2006). Forest declines are multifactorial, involving predisposing, contributing, and inciting factors acting subsequently or in synergy (e.g., Sallé et al. 2014). Drought and defoliator outbreaks are important contributing factors in the Mediterranean Basin (Franceschini et al. 2008; Tiberi et al. 2016). Bark and wood boring insects are generally considered as inciting factors during oak declines, which contribute to kill weakened trees (Sallé et al. 2014). The prominent species associated with cork oak declines are ambrosia beetles (Coleoptera: Curculionidae), longhorn beetles (Coleoptera: Cerambycidae), and buprestids (Coleoptera: Buprestidae) (Tiberi et al. 2016). Colonization of apparently healthy trees by ambrosia and longhorn beetles has also been reported, suggesting that these insects may occasionally act as contributing factors to oak declines (Sousa and Debouzie 1999; Torres-Vila et al. 2013).

The ambrosia beetle Platypus cylindrus Fab. (Coleoptera: Curculionidae, Platypodinae) has been considered one of the main causes of cork oak mortality in the Iberian Peninsula (Sousa and Débouzie 1993; Soria et al. 1994), France (Nageleisen and Hett 1989) and Morocco (Chadigan 1990). Yet, other species, in particular Xyleborus monographus Fab., Xyleborus dryographus Ratz., and Xyleborinus saxeseni Ratz. (Coleoptera: Curculionidae, Scolytinae), also occur in declining cork oak trees, frequently sharing the same trees (Catry et al. 2017). Larvae and adults of ambrosia beetles typically feed upon fungi that cover the walls of their galleries in the host plant (Beaver 1989). The fungi are transported by adults in specialized organs, the mycangia. Adult flight and tree colonization occurs normally during the warmer seasons. In the case of $P$. cylindrus, an entrance hole is initiated by the male on the tree. Then, females, attracted by the male, mate and dig transversal galleries where they inoculate the fungi and oviposit. The main signs of the presence of P. cylindrus are the small round holes on the trunk with yellow-orange sawdust and the galleries in the wood (Sousa and Debouzie 1999; Catry et al. 2017).

Although most ambrosia species are considered secondary pests, mostly affecting weakened trees, some species have become severe pests in different regions of the world. Recent examples include deciduous oak dieback in Japan by Platypus quercivorus (Murayama) (Kamata et al. 2002) and in Korea by Platypus koryoensis (Kim et al. 2009). New fungi-insect associations have been suggested to explain the increasing aggressiveness of ambrosia beetles such as Raffaelea quercivora associated with oak decline in Japan (Kubono and Ito 2002) and Raffaelea quercus-mongolicae in Korea (Kim et al. 2009). Geographical range expansions and invasive processes have instigated recent problems with ambrosia beetle species. For example, Megaplatypus mutatus (Chapuis), native to the subtropical and tropical areas of South America, is expanding into temperate regions where it causes damage to poplars, willows and other broadleaf species (Alfaro et al. 2007). Other possible causes are an increase of tree susceptibility due to climate or anthropogenic factors. Still, the relevance of these factors remains relatively understudied. 
The attack densities by $P$. cylindrus differ considerably among regions in the Mediterranean Basin. In Portugal, tree mortality attributed to $P$. cylindrus is high and this beetle is considered a primary pest able to attack healthy trees (Sousa and Debouzie 1999). In Morocco, the beetle is also considered a primary pest (Villemant and Fraval 1993). However, in Tunisia and Italy, the insect has been described as a secondary pest colonizing only weakened or dead trees (Bellahirech et al. 2014).

In Tunisia, cork oak woodlands occupy a northern strip between the coastal mountains and the Mediterranean Sea. Its core area is located in the Northwest, between the Algerian frontier and the city of Sejnene. Cork oak is also found farther east, near Bizerte, with minor stands in Zaghouan, approximately $50 \mathrm{~km}$ from the capital and next to Cap Bon (Nabeul governorate), the eastern most population in the country. The species extends over an area of 70,113 ha (Selmi et al. 2010). Cork oak shares its territory with maritime pine in drier habitats and with $Q$. canariensis and $Q$. afares in humid sites. Although P. cylindrus has been described as secondary pest in Tunisia, so far, there is no data on its distribution and attack densities. Further, there is a lack of information on the conditions of cork oak forests in Tunisia, such as the importance, frequency and intensity of cork oak decline. We hypothesize that climate warming observed in recent decades might have had a predisposing negative effect on cork oaks, as observed in other regions of the Mediterranean Basin. We further question whether ambrosia beetles could be a major contributing or inciting factor to cork oak decline. This knowledge would further help to recommend adequate management practices. To achieve this goal, field surveys were conducted in several localities during 2 years in North Tunisia. Tree health status, presence of biotic agents, tree dendrometric traits and debarking intensity were recorded as well as site variables (soil, understory, and climate). Frequency and attack densities by ambrosia beetles were then related through generalized linear models to tree- and site-level variables.

\section{Materials and methods}

\subsection{Study sites}

Field surveys were carried out in 15 sites in North Tunisia (Figs. 1 and 2). The ages of cork oak in the studied sites varied from 90-100 years old (Babouch) to 200-250 years old (El Jouza). The altitude gradient (meters above sea level) ranged from $207 \mathrm{~m}$ (in Babouch) to $773 \mathrm{~m}$ (in Ain Soltan) (Table 1). The understory of the study forests contained a diversity of shrub species, namely Pistacia lentiscus, Quercus coccifera, Erica arborea, Myrtus communis, Smilax aspera, Phillyrea media, Arbutus unedo, and Lavandula stoechas, with a varying density (Table 1).
Shrubs were dense in the majority of sites, in particular in Babouch, Mzara, Sidi Badr, Tabouba and Fernana. However, shrubs had low density in some forests (Ain Drahem, El Jouza and Hamdia).

The work was conducted in 2010 and 2011. At each site, one pure cork oak stand, $Q$. suber, was chosen based on the year of debarking (i.e., previous year). Trees from the same plot were all debarked in the same year. We selected only stands with trees debarked in the previous year. Insect holes were inspected only on the debarked surface due to the clear discernibility of holes. Insect holes were inspected only on the debarked surface because it is more difficult to distinguish holes on the roughly textured cork, which could thus underestimate the number of holes. Tree density ranged between 130 and 200 trees/ha (Table 1). For each stand, 25-75 recently debarked trees were sampled. Trees were chosen by rotating clockwise from a central point one full turn. All trees within a turn were considered.

Meteorological data (average values in 2010 and 2011), mean annual temperature $\left({ }^{\circ} \mathrm{C}\right)$ and total annual precipitation $(\mathrm{mm})$ were obtained from meteorological stations of the National Institute of Meteorology (NIM) in Tunisia located in Bizerte, Jandouba, Beja and Tabarka (www.meteo.tn). Average annual precipitation ranged from 600 to $1780 \mathrm{~mm}$, and average annual temperature ranged from 12 to $21{ }^{\circ} \mathrm{C}$ (Table 1).

\subsection{Data collection and analysis}

On each sampled tree, two dendrometric parameters were measured: the mean crown diameter $(\mathrm{CD}, \mathrm{m})$ and diameter at breast height $(\mathrm{DBH}, \mathrm{m})$. Phytosanitary conditions were assessed using the following variables: presence/absence of crown yellowing, trunk diseases, trunk cavities, and crown defoliation classes $(0-$ no defoliation; $1-1-33 \%$; $2-33-$ $66 \%, 3 \longrightarrow 66 \%)$. The following management variables were assessed: Presence/absence of understory, debarking height $(\mathrm{m})$, and number of scars caused by debarking. The debarked part of trunk was observed for the presence of ambrosia beetle holes up to a maximum of $2 \mathrm{~m}$ height. It has to be noted that the majority of holes are usually found at the base of the tree trunk up to $1.5 \mathrm{~m}$ height (Fig. 1). The presence of characteristic entrance holes (1-2 mm diameter) on the tree trunk and typical thin yellowish saw dust confirm the presence of P. cylindrus or other ambrosia beetles attack (Soria et al. 1994; Catry et al. 2017). We use the term ambrosia beetles throughout the paper because we could not separate the ambrosia beetle species responsible for the attacks. Although $P$. cylindrus is probably the major species, other ambrosia beetles, namely $X$. monographus, $X$. dryographus and $X$. saxeseni, may collaboratively induce the damage in the same tree and even share the same exit holes (Catry et al. 2017). The presence of other insects was also noted, such as 
Fig. 1 Photos of two studied stands. a Choucha forest. b Ain Drahem forest, and symptoms on Quercus suber after the attack of Platypus cylindrus in Ain Drahem stand $(\mathbf{c}, \mathbf{d})$ : arrowed, sign of the presence of Platypus cylindrus on the trunk: yellow-orange sawdust coming out of the entry holes (Photos: A. Bellahirech)
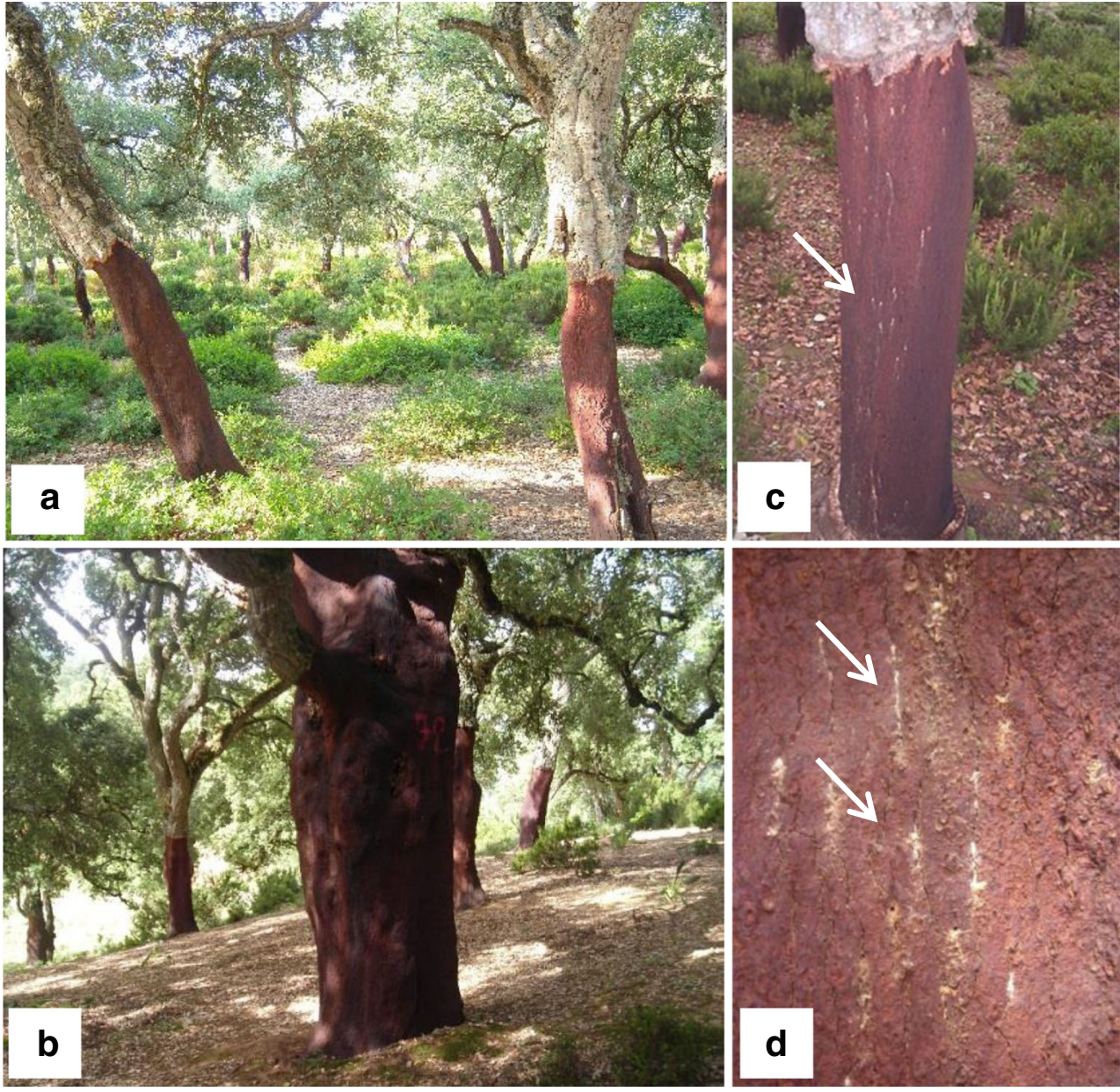

observing the exit holes of longhorn beetles (> $2 \mathrm{~mm}$ diameter).

Data analysis was performed at the site-level ( $n=15$ sites) and at the tree level ( $n=729$ trees). The following variables were recorded: (1) site-level explanatory variables: altitude (A, m), temperature $\left(\mathrm{T},{ }^{\circ} \mathrm{C}\right)$, precipitation $(\mathrm{P}, \mathrm{mm})$ (Table 1); (2) tree dendrometric variables: DBH (m), CD (m); (3) management variables: debarked height $(\mathrm{m})$, debarked surface $\left(\mathrm{m}^{2}\right)$; and (4) phytosanitary status: presence of trunk decay cavities (PTC, binary variable; yes/no), presence of trunk diseases (PTD, binary variable; yes/no), presence of crown yellowing (PCY, binary variable; yes/no), number of trunk scars (count), crown defoliation classes (four ordinal defoliation categories as indicated above) (Table 2; Bellahirech et al. 2019). Correlations between variables were assessed (Pearson or Spearman according to data).

\subsection{Site-level analysis}

For the site-level analyses, we used the following indicators of ambrosia beetle attacks in each site as dependent variables: (i) proportion of attacked trees (0-1) and (ii) average density of beetle holes per square meter. Beetle attacks were examined in relation to the different explanatory variables that were collected at the site level (altitude, temperature, precipitation and understory presence) and at the tree level (mean tree DBH, mean area debarked, proportion of trees with trunk cavities, proportion of trees with trunk diseases, proportion of trees with yellowing crown, mean number of trunk scars per tree, mean number of defoliation class per tree). We used generalized linear models (GLM) to analyze the proportion of trees with beetle holes, and the average density of ambrosia beetle holes per square meter (Binomial and Gaussian distributions, respectively) in relation to site variables. Prior to model building, correlation between variables was checked (Pearson correlation coefficient). When correlation was greater than 0.60 , only one variable was used in order to avoid collinearity problems (Zuur et al. 2009).

We assessed the extent of potential spatial autocorrelation in our data (both raw ambrosia beetle presence data and Pearson model residuals) by looking at spline correlograms produced using the ncf $\mathrm{R}$ package (Zuur et al. 2009). With this method, a plot of the correlogram function against distance is produced, and 95\% confidence intervals are superimposed. The analyses performed did not show significant spatial auto-correlation between 
Fig. 2 Location of the three governorates, which include 15 studied sites in the North of Tunisia (left). Site localization; circles are proportional to the percentage of attacked trees on each site (right)

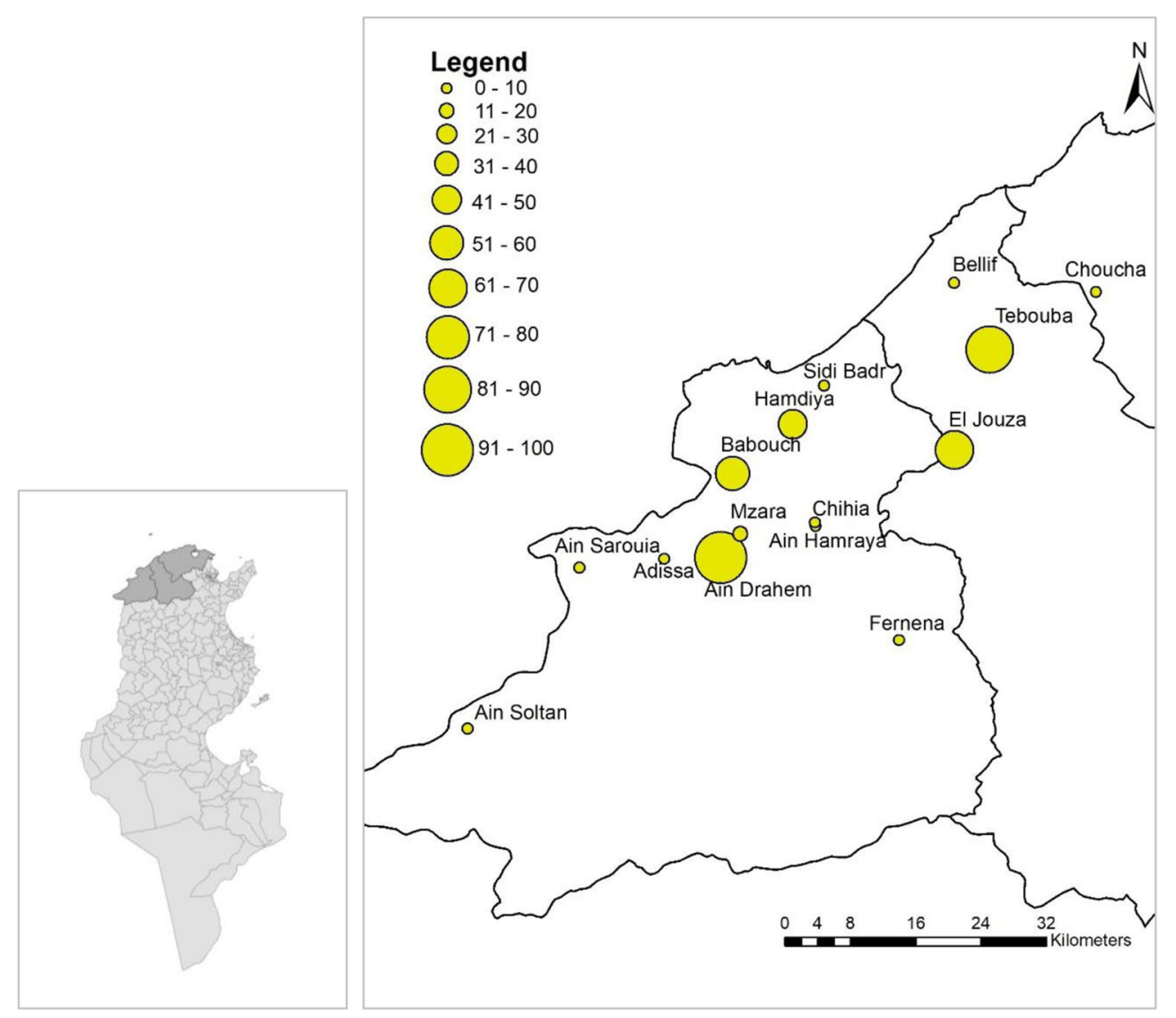

sites. Finally, because correlation coefficients only show pairwise correlations, we used variance inflation factors (VIF) to assess which explanatory variables were collinear and should be dropped before starting the analyses (Zuur et al. 2009). No formal cutoff value or method exists to determine when a VIF is too large (O'Brien 2007; Zuur et al. 2009). In this study, we opted for a conservative approach and selected a final set of explanatory variables with VIF $<3$ (Zuur et al. 2009), using the $u s d m$ R package (Naimi et al. 2014).

Table 1 Site variables

\begin{tabular}{llllllllll}
\hline Site & Number trees & Year & Long. & Lat. & Elevation $(\mathrm{m})$ & Precip. $(\mathrm{mm})$ & Temp. $\left({ }^{\circ} \mathrm{C}\right)$ & Understory & Tree density $\left(\mathrm{N}\right.$ ha $\left.{ }^{-1}\right)$ \\
\hline Adissa & 50 & 2011 & 8.615 & 36.740 & 386 & 900 & 17.0 & Open & 180 \\
Ain Drahem & 75 & 2010 & 9.050 & 36.990 & 728 & 1780 & 20.8 & Open & 150 \\
Ain Hamraya & 51 & 2011 & 8.824 & 36.783 & 609 & 1400 & 15.0 & Dense & 130 \\
Ain Sarouia & 51 & 2011 & 8.499 & 36.731 & 298 & 1300 & 14.8 & Dense & 150 \\
Ain Soltan & 46 & 2011 & 8.347 & 36.552 & 773 & 1570 & 11.7 & Open & 160 \\
Babouch & 50 & 2011 & 8.709 & 36.836 & 207 & 950 & 20.0 & Dense & 150 \\
Bellif & 51 & 2011 & 9.014 & 37.047 & 277 & 879 & 18.8 & Dense & 180 \\
Chihia & 50 & 2011 & 8.823 & 36.782 & 450 & 1000 & 17.0 & Dense & 180 \\
Choucha & 51 & 2011 & 9.210 & 37.037 & 307 & 878 & 16.0 & Open & 130 \\
El Jouza & 25 & 2010 & 9.014 & 36.860 & 520 & 1222 & 16.0 & Open & 200 \\
Fernana & 50 & 2011 & 8.938 & 36.650 & 375 & 600 & 12.0 & Dense & 200 \\
Hamdia & 51 & 2011 & 8.792 & 36.891 & 306 & 800 & 15.0 & Open & 180 \\
Mzara & 52 & 2011 & 8.720 & 36.769 & 653 & 900 & 13.5 & Dense & 200 \\
Sidi Badr & 51 & 2011 & 8.835 & 36.933 & 234 & 1200 & 15.9 & Dense & 180 \\
Tabouba & 25 & 2010 & 9.063 & 36.970 & 333 & 800 & 18.2 & Dense & 150 \\
\hline
\end{tabular}


Table 2 Stand dendrometric and phytosanitary variables (mean $\pm \mathrm{se})$

\begin{tabular}{llllllllrrr}
\hline Site & DBH & DS & PTC & PTY & PTD & DC & NS & PH & NH & DH \\
\hline Adissa & $0.44 \pm 0.01$ & $2.98 \pm 0.13$ & 14 & 54 & 24 & $1.3 \pm 0.09$ & $26 \pm 1.2$ & 0 & $0 \pm 0$ & $0 \pm 0$ \\
Ain Drahem & $0.52 \pm 0.02$ & $4.65 \pm 0.29$ & 23 & 56 & 39 & $0.7 \pm 0.07$ & $42 \pm 2.3$ & 100 & $19 \pm 2.1$ & $4.6 \pm 0.6$ \\
Ain Hamraya & $0.20 \pm 0.01$ & $1.12 \pm 0.06$ & 8 & 55 & 12 & $1.9 \pm 0.12$ & $16 \pm 0.8$ & 4 & $0.3 \pm 0.3$ & $0.4 \pm 0.4$ \\
Ain Sarouia & $0.31 \pm 0.01$ & $1.89 \pm 0.11$ & 27 & 67 & 24 & $1.5 \pm 0.11$ & $27 \pm 1.1$ & 4 & $1.3 \pm 1.0$ & $1.0 \pm 0.8$ \\
Ain Soltan & $0.23 \pm 0.01$ & $1.39 \pm 0.12$ & 15 & 76 & 11 & $0.9 \pm 0.08$ & $27 \pm 1.5$ & 4 & $0.7 \pm 0.6$ & $0.3 \pm 0.3$ \\
Babouch & $0.32 \pm 0.01$ & $2.05 \pm 0.17$ & 29 & 76 & 30 & $1.1 \pm 0.1$ & $26 \pm 1.3$ & 56 & $8.1 \pm 1.8$ & $4.1 \pm 0.9$ \\
Bellif & $0.28 \pm 0.01$ & $1.55 \pm 0.11$ & 37 & 16 & 29 & $0.4 \pm 0.09$ & $23 \pm 1.1$ & 2 & $0.4 \pm 0.4$ & $0.1 \pm 0.1$ \\
Chihia & $0.28 \pm 0.02$ & $1.59 \pm 0.14$ & 24 & 60 & 36 & $1 \pm 0.11$ & $26 \pm 1.9$ & 4 & $0.7 \pm 0.6$ & $0.3 \pm 0.3$ \\
Choucha & $0.24 \pm 0.01$ & $1.20 \pm 0.08$ & 18 & 51 & 37 & $2.4 \pm 0.09$ & $15 \pm 1$ & 8 & $0.4 \pm 0.3$ & $0.3 \pm 0.2$ \\
El Jouza & $0.39 \pm 0.03$ & $2.09 \pm 0.17$ & 48 & 16 & 16 & $0.5 \pm 0.1$ & $21 \pm 1.4$ & 68 & $4.6 \pm 1.2$ & $2.7 \pm 0.8$ \\
Fernana & $0.25 \pm 0.02$ & $1.51 \pm 0.14$ & 27 & 58 & 34 & $1.1 \pm 0.11$ & $32 \pm 1.6$ & 10 & $4.4 \pm 2.3$ & $3.5 \pm 2.3$ \\
Hamdia & $0.28 \pm 0.01$ & $1.60 \pm 0.10$ & 14 & 49 & 25 & $1.2 \pm 0.07$ & $23 \pm 1.3$ & 47 & $6.4 \pm 1.5$ & $4.2 \pm 0.9$ \\
Mzara & $0.32 \pm 0.02$ & $1.95 \pm 0.13$ & 6 & 65 & 54 & $0.9 \pm 0.08$ & $25 \pm 1.4$ & 15 & $1.8 \pm 0.7$ & $1.0 \pm 0.4$ \\
Sidi Badr & $0.30 \pm 0.01$ & $1.68 \pm 0.12$ & 20 & 12 & 8 & $1.1 \pm 0.13$ & $25 \pm 1.3$ & 6 & $0.5 \pm 0.4$ & $0.5 \pm 0.4$ \\
Tabouba & $0.30 \pm 0.02$ & $1.87 \pm 0.13$ & 100 & 36 & 0 & $0.6 \pm 0.12$ & $7 \pm 0.8$ & 88 & $4.2 \pm 0.6$ & $2.2 \pm 0.3$ \\
\hline
\end{tabular}

$D B H$ mean diameter at breast height $(\mathrm{m}), D S$ mean debarked surface $\left(\mathrm{m}^{2}\right), P T C$ proportion of trees with trunk cavities $(\%), P T Y$ proportion of trees with crown yellowing (\%), PTD proportion of trees with trunk diseases signs (\%), DC mean class of crown defoliation (classes $=0,1,2,3$ ), $N S$ mean number of trunk scars per tree, $\mathrm{PH}$ proportion of trees with holes of ambrosia beetles, $\mathrm{NH}$ mean number of holes of ambrosia beetles per tree, $\mathrm{DH}$ mean density of holes of ambrosia beetles (holes $/ \mathrm{m}^{2}$ )

In all cases, we started with a model including all variables and used backward elimination (based on $F$ tests) to select the most important ones (Zuur et al. 2009). All GLM analyses were performed using $\mathrm{R}$ ( $\mathrm{R}$ Core Team 2017) and the MASS package (Venables and Ripley 2002). In the binomial GLM, we detected over dispersion and corrected the standard errors using a quasi-GLM model (quasi-binomial). Additionally, since the number of trees assessed varied across sites, we included the number of trees per site as weights, which is an appropriated way to represent the number of trials when the response is the proportion of successes (Zuur et al. 2009). The Nagelkerke pseudo- $R^{2}$ (Nagelkerke 1991) was used as an indicator of the proportion of variance explained by the models.

\subsection{Tree-level analysis}

For the tree-level analysis, we used the number of beetle holes in each tree as indicator of the presence and of intensity of beetle attacks. Beetle attacks were examined in relation to different explanatory variables that were assessed in each tree $(\mathrm{DBH}$, crown diameter, presence of trunk cavities, presence of trunk diseases, and number of trunk scars).

We used generalized linear mixed models (GLMM) to analyze the beetle attacks in relation to different variables in two steps. In a first step, we analyzed the presence and absence of beetle holes (binomial) considering all sampled trees $(n=729)$. In a second step, we analyzed the density of beetle holes (i.e., the number of holes per square meter; Gaussian distribution) considering only the trees where the presence of beetles was detected $(n=196)$. We included a term for the study sites as a random effect, as we expect that observations within sites are not independent (i.e., the presence and density of beetle holes at trees on the same site are likely to be more similar to each other than to values from different sites).

Similar to the site-level analysis and prior to model building, we checked correlation between explanatory variables (Pearson correlation coefficient and VIFs). In all cases, we started with a model including all variables and used backward elimination (based on likelihood ratio test) to select the most important ones. Several alternative models were tested and selected using the Akaike information criterion (AIC). The Nagelkerke pseudo- $R^{2}$ (Nagelkerke 1991) was used as an indicator of the proportion of variance explained by the models. Additionally, for binomial GLMM, we used the area under the receiver operating characteristics (ROC) curve (Pearce and Ferrier 2000), which evaluates model performance in both threshold- and prevalence-independent fashion (Hosmer and Lemeshow 2000). The area under the ROC curve is typically evaluated as follows: values between 0.5 and 0.7 indicate low accuracy, values between 0.7 and 0.9 informative applications, and values above 0.9 high accuracy (Swets 1988). All modeling analyses were performed 
Fig. 3 Mean number ( \pm SE) of beetle holes per tree in each one of the 15 study sites ( $n=729$ trees)

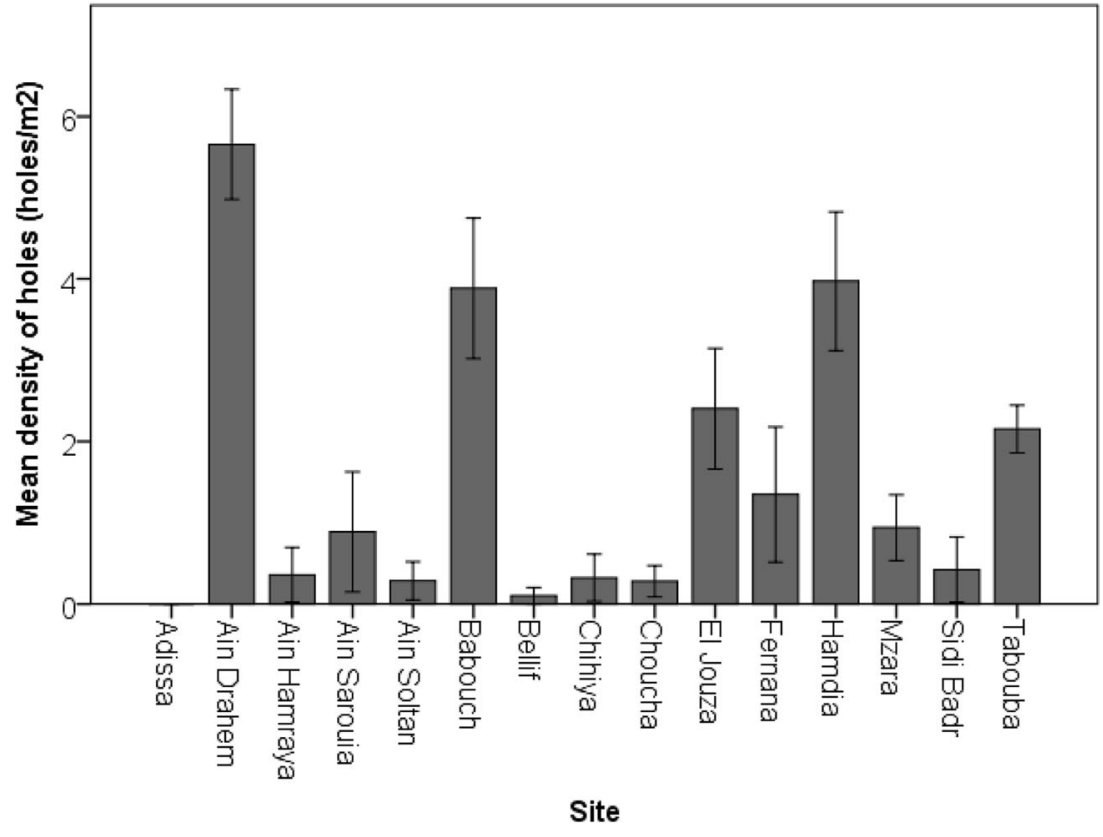

Error bars: +/- $1 \mathrm{SE}$ using $\mathrm{R}$ ( $\mathrm{R}$ Core Team 2017) and the lme4 package (Bates et al. 2015).

\section{Results}

\subsection{Site differences}

The proportion of trees infested by ambrosia beetles differed significantly among the 15 sites (Wald $\chi^{2}=157.20, d f=14$, $P<0.001)$. Five sites showed a high proportion of infested trees, namely Ain Drahem (100\%), Tabouba (88\%), El Jouza (68\%), Babouch (55\%), and Hamdia (47\%) (Figs. 2 and 3$)$. In contrast, the proportions of attacked trees in nine sites were lower than $8 \%$, and in one site (Adissa), there were no attacked trees. No clear geographical distribution pattern is apparent (Fig. 2).

As expected, since debarking area is proportional to tree size, average DBH was highly correlated with debarked surface $(r=0.95, P<0.001)$ as well as with debark height $(r=$ $0.78, P=0.001)$. These two variables were also highly correlated $(r=0.93, \mathrm{p}<0.001)$. The two sites with largest $\mathrm{DBH}$ also showed the highest debarked surface (Table 2). Debarked surface and number of trunk scars were further positively correlated $(r=0.61, P=0.016)$.

The attack densities, expressed by the number of holes per debarked area, also differed between sites $\left(F_{14,716}=4.804\right.$, $P<0.001$ ) (Table 2 ). When analyzing the mean number of holes per tree, the effect of site was again significant $\left(F_{14,716}=20.601, P<0.001\right)$. Ain Drahem was the most affected site by ambrosia beetles, presenting a mean of 19 holes/ tree and a density of 4.6 holes $/ \mathrm{m}^{2}$. Subsequently, Babouch and Hamdia also showed high infestations, with mean values of 6.4 and 8.1 holes/tree and 4.0 and 4.2 holes $/ \mathrm{m}^{2}$, respectively.

Only 14 trees exhibited holes of cerambycids, which was greatly inferior to the number of trees with ambrosia beetles holes $(n=196)$. These 14 trees included three trees from Ain Drahem, five from Babouch and two from each of three other sites, Chihia, Fernana, and Mzara. All trees with exit holes of cerambycids were also attacked by ambrosia beetles. At site level, a significant Spearman correlation was found between the number of trees with exit holes of cerambycids and the mean number of ambrosia holes per tree $(r=0.581, P=0.023)$.

\subsection{Site-level analysis}

The models developed show that beetle attacks, expressed by the proportion of trees with beetle holes,

Table 3 Generalized linear mixed models showing the variables affecting the proportion of trees with beetle attacks ( $n=15$ sites). Two alternative univariate models with very similar performance are presented

\begin{tabular}{llrlll}
\hline & & \multicolumn{1}{l}{ Coefficients } & $F$ value & $d f$ & $P$ value \\
\hline Model 1 & $\beta_{0}$ & $-8.995 \pm 3.203$ & - & - & - \\
& Temp & $0.473 \pm 0.183$ & 8.018 & 1 & 0.014 \\
\multirow{2}{*}{ Model 2 } & $\beta_{0}$ & $-5.178 \pm 1.732$ & - & - & - \\
& DBH & $12.595 \pm 4.975$ & 8.014 & 1 & 0.025 \\
\hline
\end{tabular}

Model coefficients ( \pm standard error): $\beta_{0}$, intercept; Temp, site mean annual temperature $\left({ }^{\circ} \mathrm{C}\right)$; DBH, diameter at breast height $(\mathrm{m})$. Result of the $F$ test ( $F$ value and respective $P$ value and $d f$ : degree of freedom). Model fit: Nagelkerke $R^{2}=0.38$ in both models 

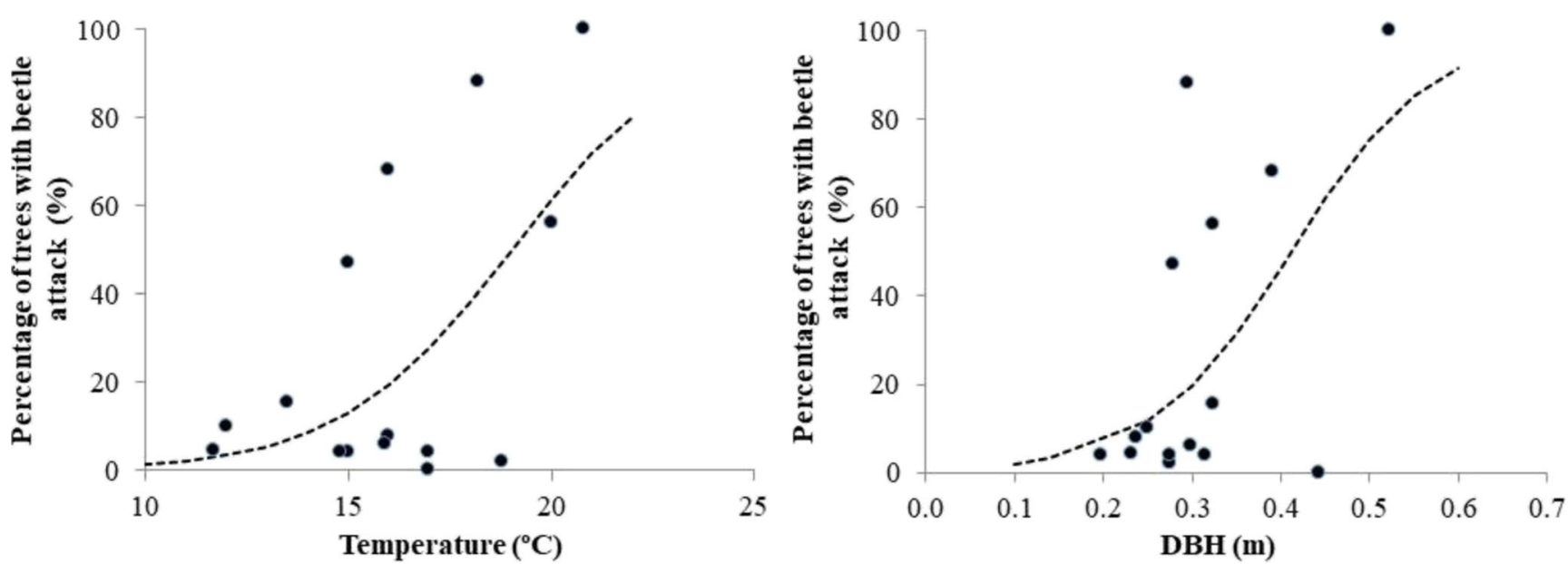

Fig. 4 Mean proportion (\%) per site of trees with beetle attacks as a function of the mean annual temperature $\left({ }^{\circ} \mathrm{C}\right)($ left $)$ and $\mathrm{DBH}($ right). The line represents the logistic curve by using estimates in Table 3

were significantly and positively related with the mean annual temperature of the sites, and with tree diameter (Table 3; Fig. 4). Still, there are five stands with average temperatures varying from 16 to $19{ }^{\circ} \mathrm{C}$ for which temperature seemed to be unassociated with attacks (Fig. 4). A model with temperature alone, or alternatively with DBH, explained $38 \%$ of the deviance (Table 3). Beetle attacks at the site-level, expressed by the average density of holes per square meter, were also significantly and positively related with temperature and tree DBH (explained deviance was $30 \%$ and $38 \%$, respectively (Table 4). Similar results were observed in a model including the debarked surface instead of DBH, which is not surprising considering that both variables were highly correlated $(r=0.95)$.

\subsection{Tree-level analysis}

In total, 195 trees were attacked by ambrosia beetles. Only $33 \%$ of these trees presented signs of pathogens (trunk canker or fungi fructification), however. In contrast, $68 \%$ of the trees

Table 4 Generalized linear models showing the influence of mean annual temperature and DBH on the average density of beetle holes $(n=15$ sites $)$

\begin{tabular}{llrlll}
\hline & & \multicolumn{1}{l}{ Coefficients } & $F$ value & $d f$ & $P$ value \\
\hline Model 1 & $\beta_{0}$ & $-4.357 \pm 2.635$ & - & - & - \\
& Temp & $0.375 \pm 0.160$ & 5.476 & 1 & 0.036 \\
Model 2 & $\beta_{0}$ & $-2.263 \pm 1.465$ & - & - & - \\
& DBH & $12.631 \pm 4.459$ & 8.024 & 1 & 0.014 \\
\hline
\end{tabular}

Model coefficients ( \pm standard error): $\beta_{0}$, intercept; Temp, site mean annual temperature $\left({ }^{\circ} \mathrm{C}\right)$; DBH, mean diameter at breast height $(\mathrm{cm})$. Result of the $F$ test ( $F$ value and respective $P$ value and $d f$ : degree of freedom). Models 1 and 2 fit: Nagelkerke $R^{2}=0.30$ and 0.38 , respectively with signs of pathogens were not attacked by ambrosia beetles. Only $44 \%$ of the trees with cavities exhibited holes of ambrosia beetles. Among the trees colonized by ambrosia beetles, $19 \%$ showed no signs of decline (i.e., absence of crown yellowing or trunk cavities or cerambycid holes or pathogens). Beetle attack densities (holes $/ \mathrm{m}^{2}$ ) were significantly higher on trees with crown yellowing (Fig. 5). Still, $73 \%$ of the trees with crown yellowing were not colonized by ambrosia beetles.

The presence of beetle attacks (presence of holes) at the tree level was found to be significantly related with the presence of trunk cavities and with tree diameter (Table 5). For the two variables, the relationship was positive, meaning that there was a higher probability of beetle attacks in trees with trunk cavities and larger trees (higher DBH).

Among the trees with beetle attacks, the attack densities (expressed by the number of beetle holes as a function of the area debarked) were significantly associated with tree DBH and crown yellowing, by decreasing order of importance (Table 6). Attack densities increased with increasing crown yellowing and decreased with DBH (Table 6; Fig. 6).

\section{Discussion}

Until now, high incidence of $P$. cylindrus or other ambrosia beetles in Tunisian cork oak forests has been mostly unnoticed. Yet, our survey showed more than $50 \%$ of the trees exhibited holes of ambrosia beetles in four sites. Although we could not distinguish holes of $P$. cylindrus from other ambrosia beetles, from the literature, we hypothesize that P. cylindrus accounts for the majority of the attacks. Further studies aiming at identifying the ambrosia beetles involved in cork oak decline in Tunisia are nevertheless required. In 8 out of 15 sites, the proportion of attacked trees was very low (< $8 \%)$ and in one site was null. When analyzing predictor 

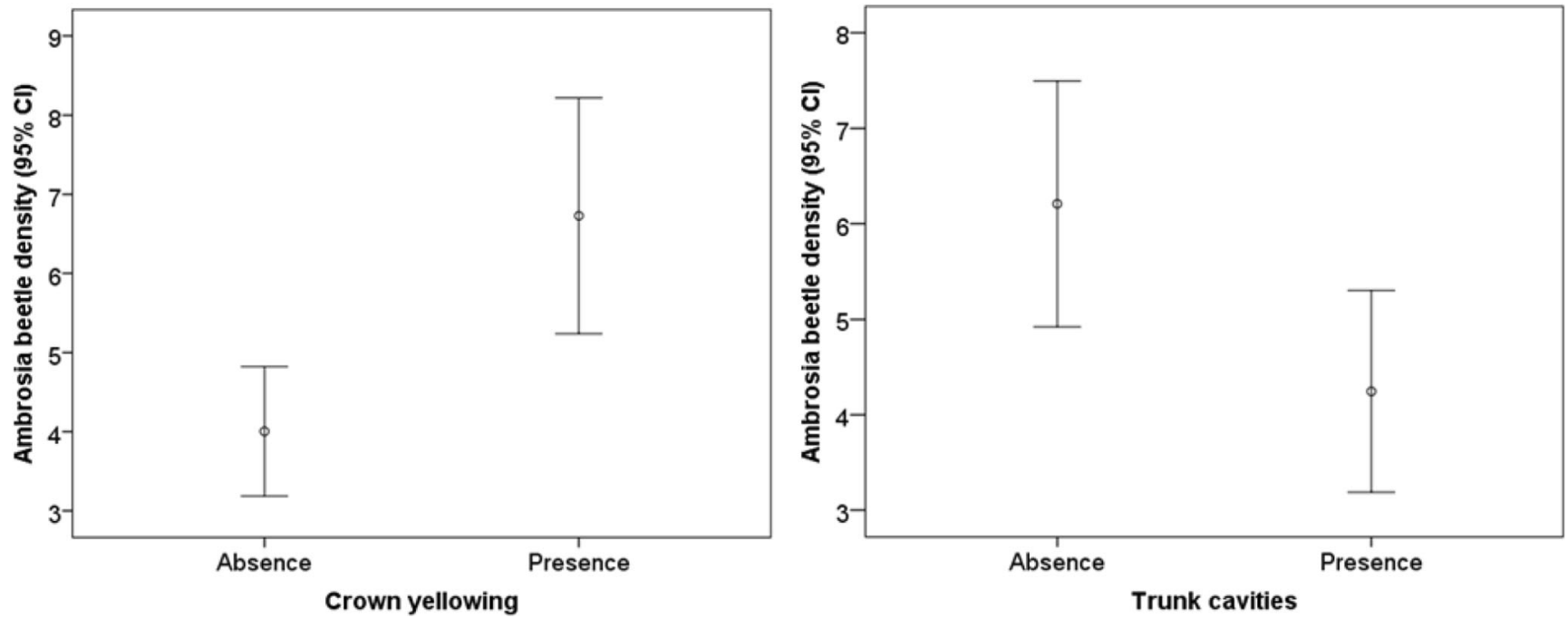

Fig. 5 Ambrosia beetle density (beetles $/ \mathrm{m}^{2}, 95 \%$ confidence intervals) in the trees where beetles were present in the presence/absence of tree crown yellowing (left) and trunk cavities (right)

variables at the site level, we found that temperature and DBH were the most important variables to explain the trends observed. Nevertheless, there are a few stands for which there are almost no attacks despite relatively high average temperature. Further data would be needed, namely on other stand management variables, to interpret this result.

Increases in annual temperature may lead to shorter life cycles and more generations per year for these insects. In the case of $P$. cylindrus, there is evidence of overlapping generations and prolonged egg laying activity which starts at the end of the summer/early fall and continues during winter until next spring (Sousa and Inácio 2005; Catry et al. 2017). Such yearround prolonged activity is likely favored by higher temperatures during winter and fall. Increased temperatures may further enhance fungi development, favoring beetle-fungal symbiotic interactions. Higher temperatures in temperate regions could also explain a general pattern observed with other ambrosia beetles that have emerged as pests in recent decades (Ploetz et al. 2013).

Table 5 Generalized linear mixed model showing the variables affecting the presence of beetle attacks in all exploited cork oaks $(n=$ 729 trees)

\begin{tabular}{lrlll}
\hline & \multicolumn{1}{l}{ Coefficients } & $\chi^{2}$ & $d f$ & $P$ value \\
\hline$\beta_{0}$ & $-3.496 \pm 0.787$ & - & - & - \\
PTC & $1.253 \pm 0.315$ & 15.186 & 1 & $<0.001$ \\
DBH & $4.651 \pm 1.190$ & 14.714 & 1 & $<0.001$ \\
\hline
\end{tabular}

Model coefficients ( \pm standard error): $\beta_{0}$, intercept; DBH, diameter at breast height (m); PTC, presence of trunk cavities (binary variable; yes/ no). Results of the likelihood ratio test ( $\chi^{2}$ and respective $P$ value and degree of freedom $(d f)$ ) to evaluate the importance of each variable (variables are ordered by decreasing order of importance). Model fit: area under the ROC curve (AUC) $=0.94$; Nagelkerke $R^{2}=0.09$
Severe drought generally makes trees more susceptible to secondary, opportunistic, pests, and diseases (Lindner et al. 2010; Jactel et al. 2012; Williams et al. 2013). However, the precipitation variable was excluded from the modeling analysis in the studied situation, ruling out an indirect effect of tree susceptibility due to water stress in this particular case. Annual rainfall was moderate to high in most of the studied sites, varying from 800 to $1780 \mathrm{~mm}$, except in one site Fernana, which exhibited $600 \mathrm{~mm}$ annual precipitation. Therefore, increased tree susceptibility to ambrosia beetles due to water stress does not seem to be the major driving factor in the present situation. Yet, because we are considering recent precipitation, we cannot exclude whether long-term drought effects could be involved. On the other hand, we may assume that high temperature and humidity may favor fungal development sustaining the beetle populations. Ambrosia fungi need humidity to develop inside trees and when transported in insects' mycangia (Beaver 1989; Blackwell and Jones 1997). The site Ain Drahem, presenting 100\% of trees with

Table 6 Generalized linear mixed model showing the variables affecting the density of beetle attacks (number of holes $/ \mathrm{m}^{2}$ ) in exploited cork oaks with beetle presence ( $n=196$ trees)

\begin{tabular}{lrlll}
\hline & \multicolumn{1}{l}{ Coefficients } & $\chi^{2}$ & $d f$ & $P$ value \\
\hline$\beta_{0}$ & $9.277 \pm 1.603$ & - & - & - \\
DBH & $-9.925 \pm 3.078$ & 10.097 & 1 & 0.001 \\
PCY & $2.576 \pm 0.908$ & 8.089 & 1 & 0.004 \\
\hline
\end{tabular}

Model coefficients ( \pm standard error): $\beta_{0}$, intercept; DBH, diameter at breast height $(\mathrm{m})$; PCY, presence of crown yellowing (binary variable; yes/no). Results of the likelihood ratio test ( $\chi^{2}$ and respective $P$ value and degree of freedom $(d f)$ ) to evaluate the importance of each variable (variables are ordered by decreasing order of importance). Model fit: Nagelkerke $R^{2}=0.12$ 

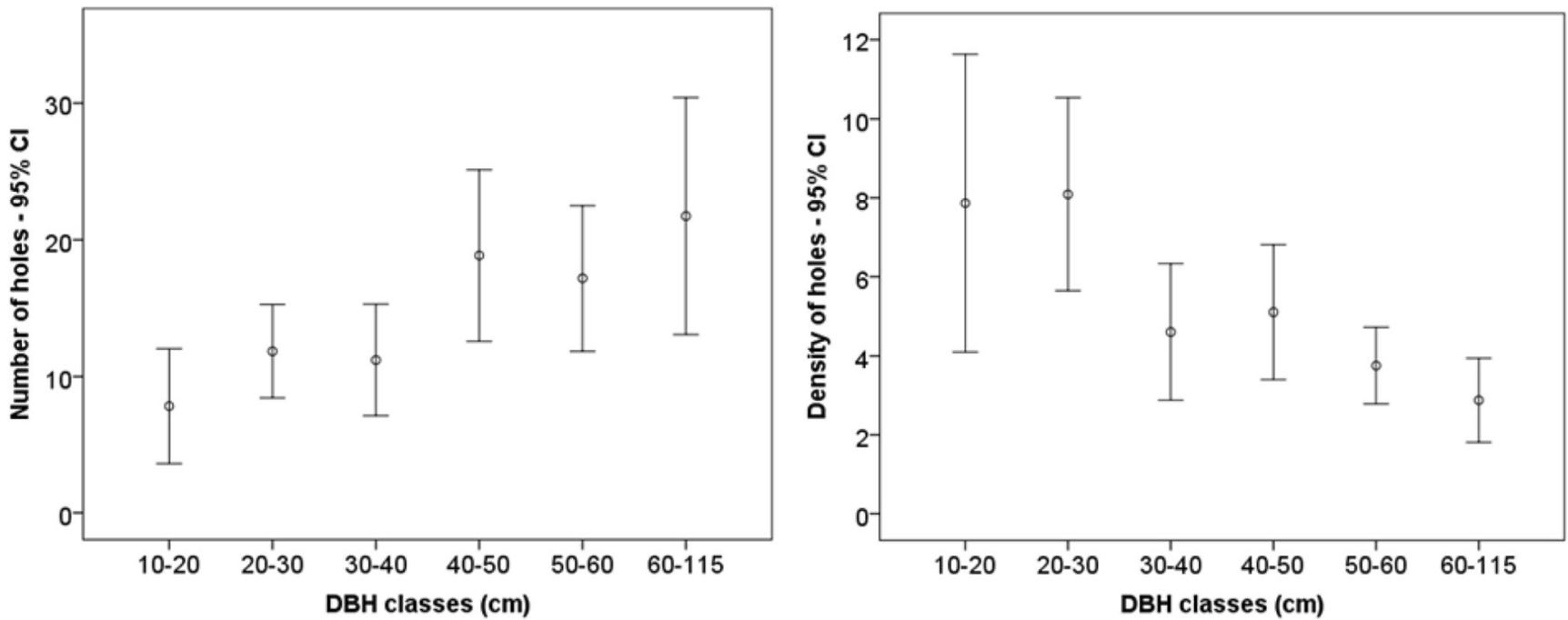

Fig. 6 Indicators of beetle attacks (95\% confidence intervals) by tree diameter classes (DBH, cm): the graphs represent the number (left) and density of holes (right) considering all trees assessed $(n=729)$

beetle attack, not only has high annual average temperature, above $20^{\circ} \mathrm{C}$, but also presents the highest annual precipitation $(1780 \mathrm{~mm})$ and highest winter humidity (Selmi 2006).

At the tree level, we found a higher risk of occurrence of ambrosia beetles in larger cork oaks, agreeing with previous findings (Sousa and Debouzie 1999; Catry et al. 2014). Attraction to host trees by ambrosia beetles can be facilitated by volatile chemical kairomones (Algarvio et al. 2002) or visual cues. Larger trees may be visually more attractive and also emit more volatiles, especially if they not only accumulate more wounds during debarking but also offer more probability for landing, which may partially explain higher probability of risk attack on bigger trees. The number of holes increased with tree size, and their density (number per $\mathrm{m}^{2}$ ) decreased with DBH. This inverse relationship is interesting and seems to contradict the hypothesis that larger trees may be more attractive due to visual or chemical cues. This finding may suggest that the higher number of holes on larger trees is primarily due to an increased probability of landing. We could not find similar results in the literature previously described.

At the tree level, we also found a high correlation between the presence of ambrosia beetle holes with tree variables such as crown discoloration and trunk cavities, both related to tree decline. Other studies have also found a preference of ambrosia beetles for weakened trees with decline symptoms (Sousa and Debouzie 1999; Catry et al. 2017). Still, the interpretation of crown discoloration is inconclusive as this symptom can be both a consequence and a predisposing factor for ambrosia beetles attack. In the present case, the density of beetle holes was higher on trees showing crown yellowing, but the opposite was found for trees exhibiting trunk cavities. Crown yellowing was not related to the presence/absence of ambrosia beetles, but only to their density, whenever beetles were present. Furthermore, the presence of crown yellowing was not related to the presence of trunk cavities or diseases. Moreover, 19\% of the trees colonized by ambrosia beetles had no signs of decline. Altogether, these results support the hypothesis that ambrosia beetles may colonize apparently healthy oaks and act as primary agents. More studies should be conducted to understand under which conditions attacks may occur. Also, among trees with signs of decline, most (69\%) were not colonized by ambrosia beetles, pointing to other causes of decline. Further studies would be required to understand why ambrosia beetles did not attempt to colonize these apparently suitable trees.

Cork harvesting, a forestry practice that involves removal of the bark from stems and main branches for this evergreen oak, is a stress factor for the tree, aggravated by the fact that it is performed during summer (Oliveira and Costa 2012). Debarking is performed periodically; initiated at approximately 20 years of age, cork harvesting occurs throughout the tree's life on approximate 9-10-year intervals. Because debarked surface was highly correlated with $\mathrm{DBH}$, and the number of trunk scars was also positively correlated with debarked surface and with DBH, we could not disentangle the effects of these variables. Other studies showed that regardless of its intensity, cork stripping favors attack by $P$. cylindrus, especially in trees exhibiting conspicuous bark wounds (Sousa and Debouzie 1999; Catry et al. 2014). Accidental wounds resulting from careless cork stripping often constitute open windows for fungal infection and insect attacks (Cabral et al. 1992; Franceschini et al. 2008; Jactel et al. 2009; Martín et al. 2005). A major conclusion is that the available information is still too scarce to allow for a consistent evaluation of the effects of cork harvesting on cork oak vulnerability to ambrosia beetles. So far, few studies have addressed how tree resilience relates to harvesting intensities, a crucial issue to enable improved tree and stand management strategies and to ensure adequate conservation of these sensitive forest systems (Oliveira and Costa 2012). 


\section{Conclusion}

A survey in Tunisian cork oak forests showed the presence of ambrosia beetles in 14 out of 15 sites. In four sites, the proportion of attacked trees exceeded 50\%. By modeling the probability of attack as a function of site variables, the annual average temperature emerged as a major environmental driver. At the tree level, increasing tree size and the presence of decline symptoms were significantly associated with increasing risks for ambrosia beetles. Preventive measures to decrease the risk of tree decline should be considered, particularly in the context of climate change with increasing temperatures. Strategies to reduce damage to trees during cork removal would likely improve stand conditions and facilitate preservation of the natural heritage of cork oak forests, particularly when faced with conditions of a changing climate and higher temperatures.

Acknowledgements The authors are highly indebted to general director of National Research Institute of Rural Engineering, Water, and Forests (INRGREF) and lab director of Laboratory of Management and Valorization of Forest Resources (LVGRF), Tunisia, who funded and assured logistic facilities (vehicle support and laboratory materials). We also thank foresters and technicians of Regional and National Forest Services for helping and facilitating fieldwork. We are grateful to two anonymous reviewers and the handling editor who provided constructive comments and recommendations, which highly contributed to improve the manuscript. Finally, the authors thank Zachary Smith, Spencer Stout, and Brian Aukema (University of Minnesota, St. Paul, Minnesota, USA) for manuscript revision.

Funding Grants for short missions have been awarded to A.B. by Ministry of High Education and Scientific Research of Tunisia (MERST), and European Forest Institute-Mediterranean (EFIMED) to visit INIAV and ISA (Lisbon, Portugal) in a context of Tunisian-Portuguese bilateral cooperation. This study is part of the $\mathrm{PhD}$ thesis of A.B. at National Institute of Agronomy, Tunis. The research is also part of project Integrated Management of Forest Ecosystems (TS-P33) Action 1.2 (Forest Protection) co-funded by JICA. F.X.C. was supported by a postdoctoral grant from Fundação para a Ciência e a Tecnologia-FCT (SFRH/BPD/ 93373/2013; POCH, EU). M.B. was supported by UID/AGR/00239/2013.

Data availability The datasets generated and/or analyzed during the current study are available in the Dryad Digital Repository. Bellahirech et al. (2019) Site- and tree-related factors affecting colonization of cork oaks Quercus suber L. by ambrosia beetles in Tunisia. Dryad. [Dataset]. https://doi.org/10.5061/dryad.686t5s2. Accessed 04 March 2019.

\section{Compliance with ethical standards}

Conflict of interest The authors declare that they have no conflict of interest.

\section{References}

Acácio V, Dias F, Catry FX, Rocha M, Moreira F (2017) Landscape dynamics in Mediterranean oak forests under global change: understanding the role of anthropogenic and environmental drivers across forest types. Glob Chang Biol 23:1199-1217
Alfaro RI, Humble LM, Gonzalez P, Villaverde R, Allegro G (2007) The threat of the ambrosia beetle Megaplatypus mutatus (Chapuis) (= Platypus mutatus Chapuis) to world poplar resources. Forestry 80: 471-479

Algarvio R, Teixeira C, Barata E, Pickett J, Casas Novas P, Figueiredo D (2002) Identification of a putative aggregation pheromone from males Platypus cylindrus (Coleoptera: Platypodidae). In: Proceedings of the International Society of Chemical Ecology 19th annual meeting. University of Hamburg, Hamburg, pp 152

Aronson J, Pereira JS, Pausas JG (2009) Cork oak woodlands on the edge: ecology, adaptive management, and restoration. Island Press, Washington. 352pp

Bates D, Mächler M, Bolker B, Walker S (2015) Fitting linear mixedeffects models using lme4. J Stat Softw 67:1-48. https://doi.org/10. 18637/jss.v067.i01

Beaver RA (1989) Insect-fungus relationships in the bark and ambrosia beetles. In: Wilding N, Collins NM, Hammond PM, Webber JF (eds) Insect-fungus interactions. Academic, London, pp 121-143

Bellahirech A, Inácio ML, Bonifácio L, Nóbrega F (2014) Comparison of fungi associated with Platypus cylindrus F. (Coleoptera: Platypodidae) in Tunisian and Portuguese cork oak stands. IOBC/ WPRS Bull 101:149-156

Bellahirech A, Branco M, Catry FX, Bonifácio L, Sousa E, Ben Jamâa ML (2019) Data from: site- and tree-related factors affecting colonization of cork oaks Quercus suber L. by ambrosia beetles in Tunisia. Dryad [Dataset]. https://doi.org/10.5061/dryad.686t5s2 Accessed 04 Mar 2019

Blackwell M, Jones K (1997) Taxonomic diversity and interactions of insect-associated ascomycetes. Biodivers Conserv 6:689-699

Bugalho MN, Caldeira MC, Pereira JS, Aronson J, Pausas JG (2011) Mediterranean cork oak savannas require human use to sustain biodiversity and ecosystem services. Front Ecol Environ 9:278-286

Cabral MT, Ferreira MC, Moreira T, Carvalho EC, Diniz AC (1992) Diagnóstico das causas da anormal mortalidade dos sobreiros a Sul do Tejo. Sci Gerund 18:205-214

Campos P (2004) Towards a sustainable global economy for Mediterranean agro-forestry systems. In: Schnabel S, Gonçalves A (eds) Advances in geo ecology: sustainability of agro-silvo-pastoral systems, Dehesas, Montados, Reiskirchen. Catena, Cremlingen, pp $13-28$

Catry FX, Moreira F, Pausas JG, Fernandes PM, Rego F, Cardillo E, Curt $\mathrm{T}$ (2012) Cork oak vulnerability to fire: the role of bark harvesting, tree characteristics and abiotic factors. PLoS One 7. https://doi.org/ 10.1371/journal.pone.0039810

Catry FX, Moreira F, Rego F, Branco M, Sousa E (2014) Fire-induced bark beetle attacks in Mediterranean cork oak forests: which factors drive host selection? In: Abstracts of the 13th International Conference on Mediterranean Ecosystems, Medecos XIII, 117, Olmué, Chile. http://www.isa.ulisboa.pt/ceabn/uploads/docs/ publicacoes/Medecos Catry 2014_Cork_Oak.pdf. Accessed 15 Oct 2014

Catry FX, Branco M, Sousa E, Caetano J, Naves P, Nóbrega F (2017) Presence and dynamics of ambrosia beetles and other xylophagous insects in a Mediterranean cork oak forest following fire. For Ecol Manag 404:45-54

Chadigan M (1990) Etude des facteurs du dépérissement du chêne-liège (Quercus suber L.) associés à l'installation des xylophages en forêt de la Mamora. PhD Thesis in Biology, University of Science Mohammed V, Rabat, Morroco

Costa A, Madeira M, Lima Santos J, Oliveira A (2011) Change and dynamics in Mediterranean evergreen oak woodlands landscapes of Southwestern Iberian Peninsula. Landsc Urban Plan 102:164176

Daly H, Campos PP, Ovando P (2009) Economic analysis of cork oak woodland natural regeneration in the region of Ain Snoussi, Tunisia. In: Zapata Blanco S (ed) Cork oak woodlands and cork industry: 
present, past and future. Museu del Suro de Palafrugell Publ., Girona, pp 488-513

Franceschini A, Corda P, Marras F (2008) Phytopathological aspects in the cork oak forest management. In: Vázquez P, Pereira JH, González Pérez A (eds) Suberwood: new challenges for the integration of cork oak forests and products. Universidad de Huelva Publicaciones, Huelva, pp 97-305

Hosmer DW, Lemeshow S (2000) Applied logistic regression, 2nd edn. Wiley, New York. https://doi.org/10.1002/0471722146

Jactel H, Nicoll BC, Branco M, Gonzalez-Olabarria RJ, Grodzki W, Långström B, Moreira F, Netherer S, Orazio C, Piou D, Santos H, Schelhaas MJ, Tojic K, Vodde F (2009) The influences of forest stand management on biotic and abiotic risks of damage. Ann For Sci 66:701-701. https://doi.org/10.1051/forest/2009054

Jactel H, Petit J, Desprez-Loustau ML, Delzon S, Piou D, Battisti A, Koricheva J (2012) Drought effects on damage by forest insects and pathogens: a meta-analysis. Glob Chang Biol 18:267-276

Kamata N, Esaki K, Kato K, Igeta Y, Wada K (2002) Potential impact of global warming on deciduous oak dieback caused by ambrosia fungus Raffaelea sp. carried by ambrosia beetle Platypus quercivorus (Coleoptera: Platypodidae) in Japan. Bull Entomol Res 92:119-126

Kim KH, Choi YJ, Seo ST, Shin HD (2009) Raffaelea quercusmongolicae sp. nov. associated with Platypus koryoensis on oak in Korea. Mycotaxon 110:189-197

Kubono T, Ito SI (2002) Raffaelea quercivora sp. nov. associated with mass mortality of Japanese oak, and the ambrosia beetle (Platypus quercivorus). Mycoscience 43:255-260

Lindner M, Maroschek M, Netherer S, Kremer A, Barbati A, GarciaGonzalo J, Seidl R, Delzon S, Corona P, Kolstrom M, Lexer MJ, Marchetti M (2010) Climate change impacts, adaptive capacity, and vulnerability of European forest ecosystems. For Ecol Manag 259: 698-709. https://doi.org/10.1016/j.foreco.2009.09.023

Martín J, Cabezas J, Buyolo T, Patón D (2005) The relationship between Cerambyx spp. damage and subsequent Biscogniauxia mediterranum infection on Quercus suber forests. For Ecol Manag 216:166-174. https://doi.org/10.1016/j.foreco.2005.05.027

Mazzei A, Bonacci T, Horák J, Brandmayr P (2018) The role of topography, stand and habitat features for management and biodiversity of a prominent forest hotspot of the Mediterranean Basin: saproxylic beetles as possible indicators. For Ecol Manag 410:66-75

Mendes AMSC, Graça JAR (2009) Cork bottle stoppers and other cork products. In: Aronson J, Pereira JS, Pausas JG (eds) Cork oak woodlands on the edge. Soc Ecol Rest Int Island Press, Washington, pp $59-69$

Montoya JM (1988) Los Alcornocales. Serie de ManualesTécnicos. Ministerio de Agricultura, Pesca y Alimentación, Madrid

Nageleisen LM, Hett P (1989) Les problèmes entomologiques, pathologiques et physiologiques: Les feuillus. La Santé des Forêts [France] en 1989. Ministère de l'Agriculture et de la Pêche (DERF), Paris

Nagelkerke NJD (1991) A note on a general definition of the coefficient of determination. Biometrika 78:691-692

Naimi B, Hamm NAS, Groen TA, Kidmore AK, Toxopeus AG (2014) Where is positional uncertainty a problem for species distribution modelling? Ecography 37:191-203. https://doi.org/10.1111/j.16000587.2013.00205.x

O'Brien RM (2007) A caution regarding rules of thumb for variance inflation factors. Qual Quant 41:673-690

Oliveira G, Costa A (2012) How resilient is Quercus suber L. to cork harvesting? A review and identification of knowledge. For Ecol Manag 270:257-272

Pausas JG, Marañón T, Caldeira M, Pons J (2009) Natural regeneration. In: Aronson J, Pereira JS, Pausas JG (eds) Cork oak woodlands on the edge. Soc Ecol Rest Int Island Press, Washington, pp 115-124
Pearce J, Ferrier S (2000) Evaluating the predictive performance of habitat models developed using logistic regression. Ecol Model 133: 225-245

Pereira JS, Bugalho MN, Caldeira MC (2008) From the cork oak to cork-a sustainable system. APCOR, Portuguese Cork Association, Litografia, Coimbra

Ploetz RC, Hulcr J, Wingfield MJ, De Beer ZW (2013) Destructive tree diseases associated with ambrosia and bark beetles: black swan events in tree pathology? Plant Dis 97:856-872

R Core Team (2017) R: a language and environment for statistical computing. Foundation for Statistical Computing, Vienna

Sallé A, Nageleisen LM, Lieutier F (2014) Bark and wood boring insects involved in oak declines in Europe: current knowledge and future prospects in a context of climate change. For Ecol Manag 328:7993

Selmi K (2006) Utilisation des données et résultats de l'inventaire forestier national pour la gestion des forêts de chêne-liège en Tunisie. Ann INRGREF 9:21-30

Selmi K, Tissaoui M, Bacha S (2010) Inventaire des forêts par télédétection. Résultats du deuxième inventaire forestier et pastoral national. Direction Générale des Forêts et le Centre National de Cartographie et de Télédetection, Tunis

Silva JS, Catry FX (2006) Forest fires in cork oak (Quercus suber L.) stands in Portugal. Int J Environ Stud 63:235-257

Soria FJ, Villagran M, Del Tio R, Ocete ME (1994) Estudios prospectivos de los principales perforadores del alcanorque en la Sierra Norte de Sevilla. Bol Sanid Veg Plag 20:643-651

Sousa EM, Débouzie D (1993) Contribution à la connaissance de quelques variables sylvicoles et écologiques au coléoptère Platypus cylindrus F., ravageur du chêne liège au Portugal. Silva Lusit 1:183-197

Sousa E, Debouzie D (1999) Spatio-temporal distribution of Platypus cylindrus $\mathrm{F}$. attacks in cork oak stands in Portugal. IOBC/ wprs Bull22, pp 47-58

Sousa E, Inácio ML (2005) New aspects of Platypus cylindrus Fab.(Coleoptera: Platypodidae) life history on cork oak stands in Portugal. In: Lieutier F, Ghaioule D (eds) Entomological research in Mediterranean forest ecosystems. INRA Editions, Paris, pp 147170

Swets JA (1988) Measuring the accuracy of diagnostic systems. Science 240:1285-1293

Tiberi R, Branco M, Bracalini M, Croci F, Panzavolta T (2016) Cork oak pests: a review of insect damage and management. Ann For Sci 73: 219-232

Torres-Vila LM, Sánchez-González Á, Merino-Martínez J, PonceEscudero F, Conejo-Rodríguez Y, Martín-Vertedor D, FerreroGarcía JJ (2013) Mark-recapture of Cerambyx welensii in dehesa woodlands: dispersal behaviour, population density, and mass trapping efficiency with low trap densities. Entomol Exp Appl 149:273281

Venables WN, Ripley BD (2002) Modern applied statistics with S. Springer, Berlin. https://doi.org/10.1007/b97626

Villemant C, Fraval A (1993) La faune entomologique du chêne-liège en forêt de la Mamora (Maroc). Ecol Mediterr 19:89-98

Williams AP, Allen CD, Macalady AK, Griffin D, Woodhouse CA, Meko DM, Swetnam TW, Rauscher SA, Seager R, Grissino-Mayer HD (2013) Temperature as a potent driver of regional forest drought stress and tree mortality. Nat Clim Chang 3:292-297

Zuur AF, Ieno EN, Walker NJ (2009) Mixed effects models and extensions in ecology with R. Springer, New York

Publisher's note Springer Nature remains neutral with regard to jurisdictional claims in published maps and institutional affiliations. 